Check for updates

Cite this: RSC Adv., 2017, 7, 50701

Received 28th September 2017 Accepted 18th October 2017

DOI: 10.1039/c7ra10732c

rsc.li/rsc-advances

\section{Facile one-step hydrothermal synthesis of noble- metal-free hetero-structural ternary composites and their application in photocatalytic water purification $\uparrow$}

\author{
Yuanyuan Zhang, ${ }^{\text {a }}$ Yongchao Ma, ${ }^{a}$ Lili Wang, ${ }^{\text {a }}$ Qinxing Sun, ${ }^{a}$ Fan Zhang ${ }^{a}$ \\ and Jinsheng Shi (D) *ab
}

\begin{abstract}
The development of heterostructured and metal decorated photocatalysts using a relatively simple, efficient and economical one-step strategy is crucial for commercial applications. However, these materials are usually synthesized through two- or multi-step approach. Herein, a facile one-step hydrothermal method was used to fabricate a noble-metal-free heterostructural $\mathrm{BiOCl} / \mathrm{Bi}_{2} \mathrm{MoO}{ }_{6} / \mathrm{Bi}$ ternary composite from $\mathrm{BiOCl}$ for the first time. First, $\mathrm{BiOCl}$ was dispersed in ethylene glycol (EG), $\mathrm{H}_{2} \mathrm{O}$ and glycerol (GLY) and the $\mathrm{BiOCl} / \mathrm{Bi}_{2} \mathrm{MoO}_{6} / \mathrm{Bi}$ ternary composite was formed after $\mathrm{Na}_{2} \mathrm{MoO}_{4}$ was introduced into $\mathrm{BiOCl}$ in $\mathrm{EG}$. However, only binary $\mathrm{BiOCl} / \mathrm{Bi}_{2} \mathrm{MoO}_{6}$ and $\mathrm{BiOCl} / \mathrm{Bi}$ photocatalysts were obtained from $\mathrm{BiOCl}$ in $\mathrm{H}_{2} \mathrm{O}$ and $\mathrm{GLY}$, respectively. Using the same synthetic route, $\mathrm{BiOCl} / \mathrm{Bi}_{2} \mathrm{WO}_{6}$, $\mathrm{BiOCl} / \mathrm{Bi}_{2} \mathrm{WO}_{6} / \mathrm{Bi}$ and $\mathrm{BiOCl} / \mathrm{Bi}$ were also synthesized in $\mathrm{H}_{2} \mathrm{O}, \mathrm{EG}$ and $\mathrm{GLY}$, respectively. The photocatalytic activities of as-prepared three samples were investigated by applying them for the photocatalytic disinfection of bacteria and organic pollutant degradation. Under visible-light irradiation, the $\mathrm{BiOCl} / \mathrm{Bi}_{2} \mathrm{MoO}_{6} / \mathrm{Bi}$ ternary composite presented the highest photocatalytic activity in comparison with the other two binary samples; the water disinfection with $100 \%$ inactivation of bacteria was realized within $4 \mathrm{~h}$. The intermediates of $\mathrm{RhB}$ photodegradation were qualitatively identified by liquid chromatography tandem mass spectrometry (LC-MS/MS) and a possible mechanism and detailed degradation pathway were proposed.
\end{abstract}

\section{Introduction}

In recent years, heterostructured and metal decorated materials have drawn considerable attention for applications in electrocatalysis, ${ }^{1,2}$ sensors, ${ }^{3,4}$ solar cells, ${ }^{5,6}$ light emitting devices ${ }^{7,8}$ and particularly photocatalysis. ${ }^{9-15}$ Bismuth oxyhalides have been considered to be promising photocatalyst candidates because of their excellent chemical inertness, outstanding photocatalytic activities and low-cost. ${ }^{\mathbf{1 6}, 17}$ In particular, BiOCl, which has a layered structure with $\left[\mathrm{Bi}_{2} \mathrm{O}_{2}\right]^{2+}$ layers sandwiched between two sheets of $\mathrm{Cl}$ ions, has been proved to exhibit prominent photocatalytic ability under ultraviolet light irradiation. ${ }^{\mathbf{1 8}}$ However, the photocatalytic performance of BiOCl suffers from limited visible-light absorption due to its wide band gap $\left(E_{\mathrm{g}}=\right.$ $3.5 \mathrm{eV}) .{ }^{18-20}$ Besides, the rapid recombination of electrons and

${ }^{a}$ Qingdao Agricultural University, Department of Chemistry and Pharmaceutical Science, Chengyang District, Qingdao, P. R. China. E-mail: jsshiqn@aliyun.com; Fax: +86-0532-86080213; Tel: +86-0532-88030161

${ }^{b}$ Qingdao Bona Biomimetic Composite Reaserch Institute Co. Ltd, P. R. China

$\dagger$ Electronic supplementary information (ESI) available. See DOI: 10.1039/c7ra10732c holes can also suppress its catalytic activity during photocatalysis.

In order to solve these problems, heterostructure construction and metal decoration could be effective strategies. Heterojunctions not only can enhance the light-harvesting performance but also significantly inhibit the recombination of photogenerated electron-hole pairs. To date, heterostructured photocatalysts such as $\mathrm{BiOCl} / \mathrm{Bi}_{2} \mathrm{O}_{2} \mathrm{CO}_{3},{ }^{21} \mathrm{BiOCl} / \mathrm{BiOBr},{ }^{22}$ and $\mathrm{BiOCl} / \mathrm{Bi}_{2} \mathrm{WO}_{6}$ (ref. 23) have been developed by compositing BiOCl with other semiconductors. Bismuth molybdate outstanding photocatalytic activity in organic dye degradation and hydrogen energy production owing to its suitable band gap (2.5-2.8 eV). ${ }^{24-27}$ The band edge positions of the conduction band (CB) and valence band (VB) of BiOCl are approximately 0.26 and $3.56 \mathrm{~V}$ (vs. NHE) and for $\mathrm{Bi}_{2} \mathrm{MoO}_{6}$ are -0.34 and $2.20 \mathrm{~V}$ (vs. NHE), respectively. ${ }^{28,29}$ The overlapping band-structure of BiOCl and $\mathrm{Bi}_{2} \mathrm{MoO}_{6}$ can match well, hence $\mathrm{BiOCl} / \mathrm{Bi}_{2} \mathrm{MoO}_{6}$ was considered to build heterostructures.

Previous studies have confirmed that the incorporation of noble metals with semiconductor oxides using surface modification is an effective way to enhance their photocatalytic $\left(\mathrm{Bi}_{2} \mathrm{MoO}_{6}\right)$, belonging to the Aurivillius family of oxides, exhibits 
activity. ${ }^{30,31}$ These particles act as electron acceptors and could accelerate interfacial electron transfer because of the high Schottky barrier at the metal-semiconductor interface. ${ }^{32}$ Considering the high cost of noble metals, semi-metal bismuth (Bi), as an abundant earth element with high carrier mobility and low effective electron mass, has attracted extensive attention in photocatalysis. ${ }^{33,34}$

In general, heterostructured and metal decorated materials are synthesized through two- or multi-step process. ${ }^{35,36}$ It is a challenge to prepare these materials using a one-step procedure. In this paper, a noble-metal-free heterostructural $\mathrm{BiOCl} /$ $\mathrm{Bi}_{2} \mathrm{MoO}_{6} / \mathrm{Bi}$ ternary composite was fabricated using a facile onestep hydrothermal method for the first time. In addition, the same strategy was used to synthesize $\mathrm{BiOCl} / \mathrm{Bi}_{2} \mathrm{WO}_{6} / \mathrm{Bi}$ ternary photocatalysts. The as-prepared ternary materials present the highest photocatalytic inactivation of bacteria and RhB degradation under visible-light irradiation when compared with other binary catalysts due to the synergistic effect of the heterostructure and metal decoration. Simultaneously, the intermediates of RhB generated during photocatalysis were qualitatively identified using LC-MS/MS and a detailed degradation pathway was proposed.

\section{Experimental section}

\subsection{Materials synthesis}

The entire synthesis procedure is presented in Scheme 1. The BiOCl precursor was obtained using a facile hydrothermal method (see ESI $\dagger$ ). Initially, $3 \mathrm{~mol}$ of BiOCl was dispersed in $60 \mathrm{~mL}$ of three different solvents: $\mathrm{H}_{2} \mathrm{O}, \mathrm{EG}$ and GLY. After being stirred for $20 \mathrm{~min}, \mathrm{Na}_{2} \mathrm{MoO}_{4}$ was added into the above solutions under vigorous stirring. After $30 \mathrm{~min}$, the solutions were transferred into Teflon-lined stainless steel autoclaves and kept at $180{ }^{\circ} \mathrm{C}$ for $12 \mathrm{~h}$ and then cooled to room temperature. The

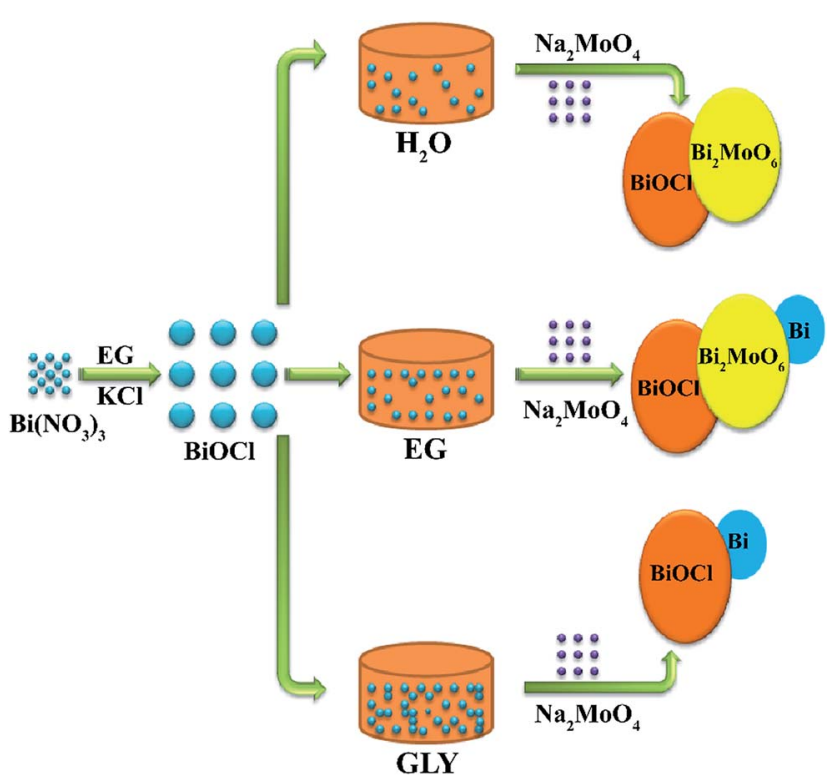

Scheme 1 Controlled fabrication of three different composites in different solutions. precipitates were collected by filtration and washed several times with deionized water. Finally, the synthesized samples were dried at $60{ }^{\circ} \mathrm{C}$ for $12 \mathrm{~h}$. Similarly, the $\mathrm{BiOCl} / \mathrm{Bi}_{2} \mathrm{MoO}_{6} / \mathrm{Bi}$ series with different $\mathrm{BiOCl} / \mathrm{Na}_{2} \mathrm{MoO}_{4}$ molar radios, $\mathrm{BiOCl} /$ $\mathrm{Bi}_{2} \mathrm{WO}_{6}, \mathrm{BiOCl} / \mathrm{Bi}_{2} \mathrm{WO}_{6} / \mathrm{Bi}$ and $\mathrm{BiOCl} / \mathrm{Bi}$ were prepared using the same route.

\section{Results and discussion}

\subsection{Electronic structure}

The electronic structure was first analyzed by means of density functional theory. Fig. $\mathrm{S} 1 \uparrow$ presents the band structures and density of states of $\mathrm{BiOCl}$ and $\mathrm{Bi}_{2} \mathrm{MoO}_{6}$. As shown in Fig. $\mathrm{S} 1 \mathrm{a}, \dagger$ the $\mathrm{VB}$ of $\mathrm{BiOCl}$ primarily comprises $\mathrm{O} 2 \mathrm{p}$ and $\mathrm{Cl} 3 \mathrm{p}$ states, while the $\mathrm{CB}$ primarily comprises $\mathrm{Bi} 6 \mathrm{p}$ and $\mathrm{O} 2 \mathrm{p}$ orbitals. In case of $\mathrm{Bi}_{2} \mathrm{MoO}_{6}$ (Fig. $\mathrm{S} 1 \mathrm{~b} \dagger$ ), the $\mathrm{VB}$ is dominantly composed of the $\mathrm{O} 2 \mathrm{p}$ orbital, while the CB is composed of Mo $4 \mathrm{~d}$, Bi $6 \mathrm{p}$ and $\mathrm{O} 2 \mathrm{p}$ states. These results suggest that the visible-light response of $\mathrm{Bi}_{2} \mathrm{MoO}_{6}$ was due to transition from the hybridized $\mathrm{Bi} 6 \mathrm{~s}$ and $\mathrm{O}$ $2 \mathrm{p}$ states in the VB to the Mo $4 \mathrm{~d}$ state in the CB. The hybridization of the $\mathrm{Bi} 6 \mathrm{~s}$ and $\mathrm{O} 2 \mathrm{p}$ states significantly enlarges the $\mathrm{VB}$, which is beneficial to the mobility of photogenerated charges and thus enhances the photocatalytic efficiency. ${ }^{37}$

\subsection{Crystal structure and XPS analysis}

The phase structure of BiOCl was examined through XRD patterns. As shown in Fig. 1a, all the diffraction peaks can be well indexed to tetragonal BiOCl (JCPDS 82-0485). No traces of other phases were discovered, indicating the high phase purity of the sample. Fig. 1b-d exhibit the XRD patterns of the different samples obtained from BiOCl in the three different solvents. It can be clearly seen that the phase composition of the as-synthesized photocatalysts was dependent on the solvent used. In $\mathrm{H}_{2} \mathrm{O}$ and $\mathrm{GLY}$, the BiOCl precursor converted to binary $\mathrm{BiOCl} / \mathrm{Bi}_{2} \mathrm{MoO}_{6}$ and $\mathrm{BiOCl} / \mathrm{Bi}$ composites, respectively. However, the $\mathrm{BiOCl} / \mathrm{Bi}_{2} \mathrm{MoO}_{6} / \mathrm{Bi}$ ternary complex was generated when EG was used as the solvent. The diffraction peaks of these samples match well with tetragonal BiOCl (JCPDS 82-0485), orthogonal $\mathrm{Bi}_{2} \mathrm{MoO}_{6}$ (JCPDS 72-1524) and rhombohedral $\mathrm{Bi}$ (JCPDS 85-1329). In addition, XPS was applied to further determine the surface chemical composition of the samples. The full scan XPS spectra of $\mathrm{BiOCl} / \mathrm{Bi}_{2} \mathrm{MoO}_{6}\left(\mathrm{H}_{2} \mathrm{O}\right)$ and $\mathrm{BiOCl} /$ $\mathrm{Bi}_{2} \mathrm{MoO}_{6} / \mathrm{Bi}$ (EG) (Fig. 2a and b) suggest that the main elements detected in the samples are $\mathrm{Bi}, \mathrm{Mo}, \mathrm{O}$ and $\mathrm{Cl}$. The signals for $\mathrm{Mo}$ $3 \mathrm{p}$ and $3 \mathrm{~d}$ at about 416.4 and $398.2 \mathrm{eV}$ (Fig. 2c) could not be observed, suggesting the absence of Mo in the resultant composite when GLY was used as the solvent. Fig. S2 $\uparrow$ shows the high resolution $\mathrm{Bi}$ if XPS spectrum of the $\mathrm{BiOCl} / \mathrm{Bi}_{2} \mathrm{MoO}_{6} / \mathrm{Bi}$ composite. The peaks at $164.9 \mathrm{eV}$ and $159.5 \mathrm{eV}$ can be attributed to $\mathrm{Bi} 4 \mathrm{f}_{5 / 2}$ and $\mathrm{Bi} 4 \mathrm{f}_{7 / 2}$, respectively. These two peaks could be further deconvoluted into two sets of peaks: (i) 164.9 and $159.5 \mathrm{eV}$ and (ii) 163.3 and $157.8 \mathrm{eV}$. Those at 164.9 and $159.5 \mathrm{eV}$ are attributed to the $\mathrm{Bi}^{3+}$ species, while those at 163.3 and $157.8 \mathrm{eV}$ were ascribed to $\mathrm{Bi} 4 \mathrm{f}_{5 / 2}$ and $\mathrm{Bi} 4 \mathrm{f}_{7 / 2}$, respectively. ${ }^{38}$ 


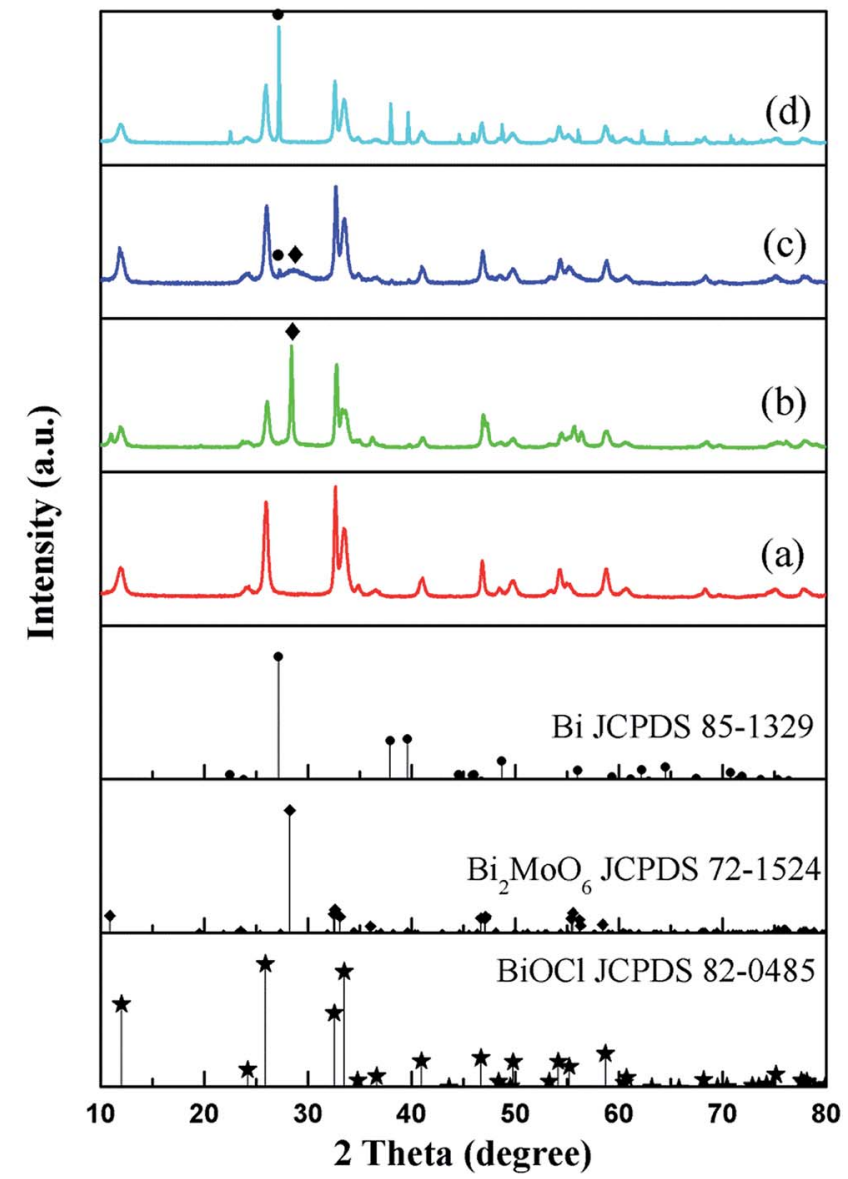

Fig. 1 XRD patterns of (a) $\mathrm{BiOCl}$, (b) $\mathrm{BiOCl} / \mathrm{Bi}_{2} \mathrm{MoO}_{6}\left(\mathrm{H}_{2} \mathrm{O}\right)$ (c) $\mathrm{BiOCl}$ $\mathrm{Bi}_{2} \mathrm{MOO}_{6} / \mathrm{Bi}(\mathrm{EG})$, and (d) $\mathrm{BiOCl} / \mathrm{Bi}(\mathrm{GLY})$.

\subsection{Morphology characteristics}

The morphology of the samples is shown in Fig. 3. As observed from the SEM images, the microstructures of the samples synthesized in the different solvents are quite different. It can be observed that the $\mathrm{BiOCl} / \mathrm{Bi}_{2} \mathrm{MoO}_{6} / \mathrm{Bi}$ ternary composite (EG) (Fig. $3 \mathrm{c}$ and d) comprises numerous hierarchical microspheres as well as some irregular nanosheets distributed among them. The size of the microspheres was relatively uniform and ranged from 1 to $2 \mu \mathrm{m}$; the thickness of the nanosheets was about $30 \mathrm{~nm}$. As shown in Fig. 3a, b, e and f, the morphologies of $\mathrm{BiOCl} / \mathrm{Bi}_{2} \mathrm{MoO}_{6}\left(\mathrm{H}_{2} \mathrm{O}\right)$ and $\mathrm{BiOCl} / \mathrm{Bi}(\mathrm{GLY})$ were similar, but very different to $\mathrm{BiOCl} / \mathrm{Bi}_{2} \mathrm{MoO}_{6} / \mathrm{Bi}$ (EG). Both of them possess evident hierarchical structures; however, the microstructures of the $\mathrm{BiOCl} / \mathrm{Bi}_{2} \mathrm{MoO}_{6}$ and $\mathrm{BiOCl} / \mathrm{Bi}$ hierarchical aggregations were composed of smaller but thicker nanosheets as compared to $\mathrm{BiOCl} / \mathrm{Bi}_{2} \mathrm{MoO}_{6} / \mathrm{Bi}$. Both of the aggregations possess a relatively uniform size ranging from 1 to $2 \mu \mathrm{m}$ and the thickness of nanosheets was about $50 \mathrm{~nm}$.

Energy disperse spectroscopy (EDS) mapping was applied to further confirm the elemental distribution on the assynthesized samples. Fig. 4a presents the hierarchical microspheres; the corresponding elemental mappings for the elements $\mathrm{Bi}, \mathrm{Mo}, \mathrm{O}$ and $\mathrm{Cl}$ are shown in Fig. 4c-f. These images show that the main elements, $\mathrm{Bi}, \mathrm{Mo}, \mathrm{O}$ and $\mathrm{Cl}$, are almost

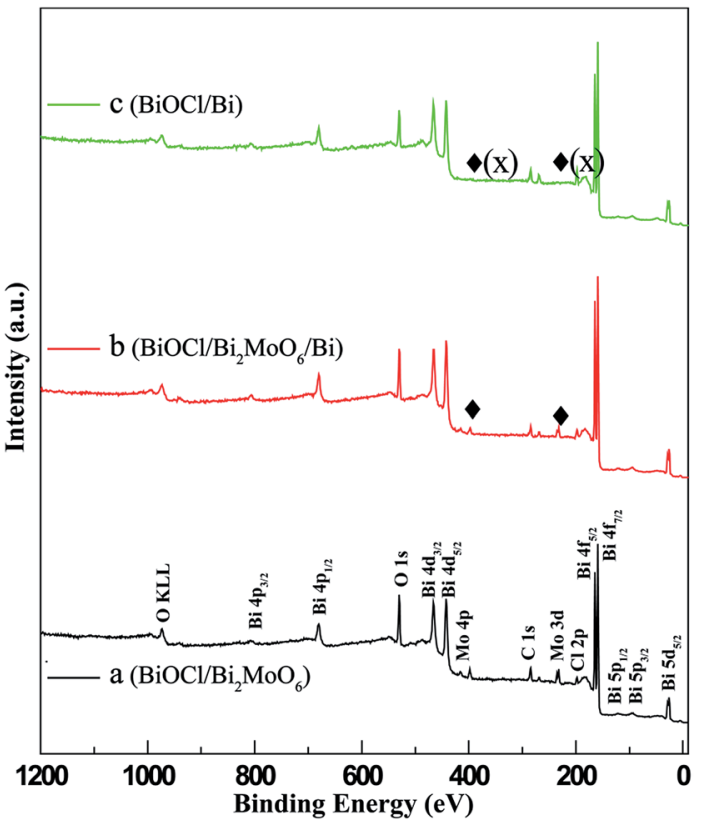

Fig. 2 XPS spectra of photocatalysts synthesized in different solvents: (a) $\mathrm{BiOCl} / \mathrm{Bi}_{2} \mathrm{MoO}_{6}\left(\mathrm{H}_{2} \mathrm{O}\right)$, (b) $\mathrm{BiOCl} / \mathrm{Bi}_{2} \mathrm{MoO}_{6} / \mathrm{Bi}(\mathrm{EG})$, and (c) $\mathrm{BiOCl} / \mathrm{Bi}$ (GLY).

uniformly distributed throughout the surface of the as-prepared sample, which further confirmed that the $\mathrm{BiOCl} / \mathrm{Bi}_{2} \mathrm{MoO}_{6} / \mathrm{Bi}$ composite was prepared successfully. Besides, the signals for $\mathrm{Bi}$, $\mathrm{Mo}, \mathrm{O}$ and $\mathrm{Cl}$ in the EDS pattern (Fig. $4 \mathrm{~b}$ ) also confirm the coexistence of these elements in the composite.
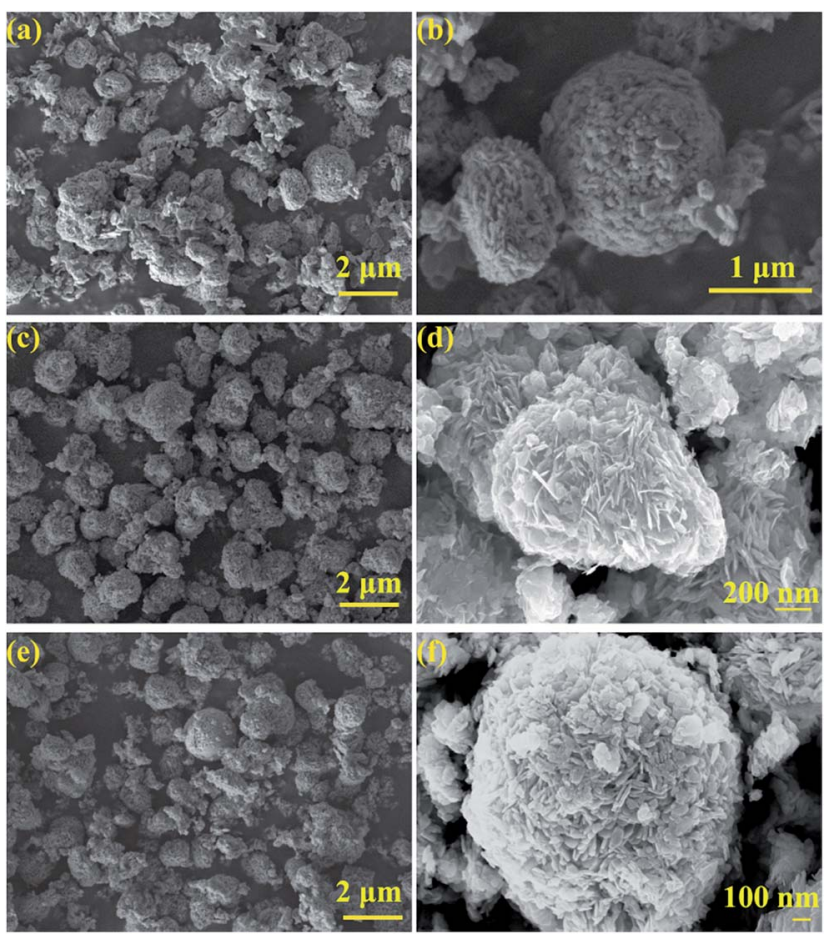

Fig. 3 SEM images of the samples formed in different solvents: $\mathrm{H}_{2} \mathrm{O}(\mathrm{a}$, b), EG (c, d), and GLY (e, f). 


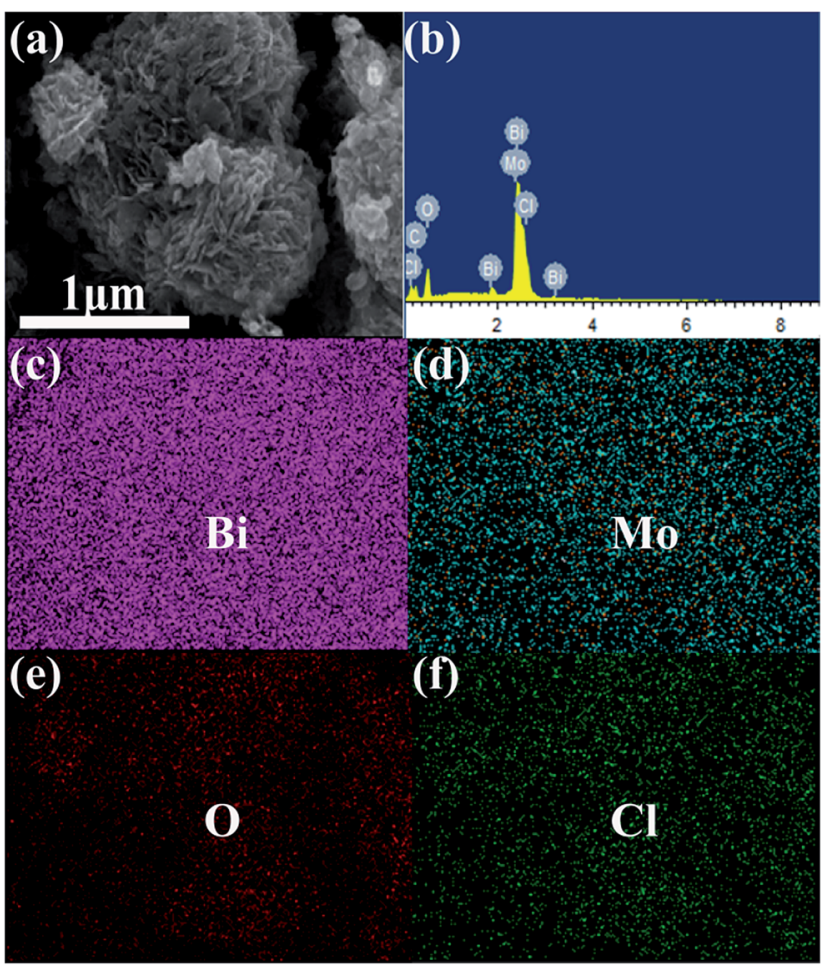

Fig. 4 SEM image (a) and EDX spectra (b) of $\mathrm{BiOCl} / \mathrm{Bi}_{2} \mathrm{MoO}_{6} / \mathrm{Bi}$; elemental distribution mapping of (c) $\mathrm{Bi}$, (d) $\mathrm{Mo}$, (e) $\mathrm{O}$ and (f) $\mathrm{Cl}$.

\subsection{Determination of the metallic Bi sites}

In order to determine the sites of Bi generated in the ternary composite, a verified experiment was carried out. First, the $\mathrm{BiOCl}$ and $\mathrm{Bi}_{2} \mathrm{MoO}_{6}$ samples were prepared and dispersed in EG, separately. Then, the suspension was subjected to the hydrothermal method. As shown in Fig. S3a, $\uparrow$ all the diffraction peaks observed for the sample can be well indexed to tetragonal BiOCl (JCPDS 82-0485) and no trace of Bi was observed. However, the signals for $\mathrm{Bi}_{2} \mathrm{MoO}_{6}$ and metallic $\mathrm{Bi}$ were both observed in Fig. S3b, $\uparrow$ confirming only $\mathrm{Bi}_{2} \mathrm{MoO}_{6}$ could be reduced by EG. Therefore, the Bi sites could be located on the surface of $\mathrm{Bi}_{2} \mathrm{MoO}_{6}$.

\subsection{Optical properties}

The UV-vis absorption characteristics of the three photocatalysts are displayed in Fig. 5. As shown in Fig. 5a, BiOCl/Bi exhibits a significantly enhanced visible-light response range than that observed in the other two samples, which can be attributed to the surface plasmon resonance (SPR) of metallic Bi. This SPR phenomenon has been reported by other groups. ${ }^{38,39}$ In case of $\mathrm{BiOCl} / \mathrm{Bi}_{2} \mathrm{MoO}_{6} / \mathrm{Bi}$ composite, the absorption from 450 to $800 \mathrm{~nm}$ was apparently stronger when compared with that observed for $\mathrm{BiOCl} / \mathrm{Bi}_{2} \mathrm{MoO}_{6}$. The enhancement in the visible-light response can be attributed to the introduction of metallic $\mathrm{Bi}^{3}{ }^{33,38}$ The optical band gap of the three composites was calculated using the formula, $\alpha h \nu=$ $A\left(h \nu-E_{\mathrm{g}}\right)^{n / 2}$, where $E_{\mathrm{g}}, h, A$ and $\alpha$ are the band gap, photonic energy, proportionality constant and optical absorption coefficient, respectively ${ }^{40}$ As shown in Fig. $5 \mathrm{~b}$, the band gaps for $\mathrm{BiOCl} / \mathrm{Bi}_{2} \mathrm{MoO}_{6}, \mathrm{BiOCl} / \mathrm{Bi}_{2} \mathrm{WO}_{6} / \mathrm{Bi}$ and $\mathrm{BiOCl} / \mathrm{Bi}$ were determined to be $1.98,2.48$ and $3.04 \mathrm{eV}$, respectively.

\subsection{Photocatalytic disinfection and organic dye degradation}

Photocatalytic inactivation of bacteria using the as-prepared three samples was examined and the corresponding results are shown in Fig. 6. In Fig. 6a, it could be observed that the three catalysts show negligible disinfection efficiencies under dark environment, suggesting that the materials themselves show almost no disinfection ability toward Staphylococcus aureus. The results obtained for the photocatalytic disinfection of Staphylococcus aureus in the presence of the samples and visible-light irradiation are presented Fig. 6b. A light control experiment with only visible-light irradiation was also investigated and the result demonstrated that almost no bacteria are disinfected, while the photocatalytic inactivation efficiencies would largely improve under visible-light irradiation in comparison with those under dark conditions. As shown in Fig. 6b, the BiOCl/ $\mathrm{Bi}_{2} \mathrm{MoO}_{6} / \mathrm{Bi}$ ternary composite displays the highest
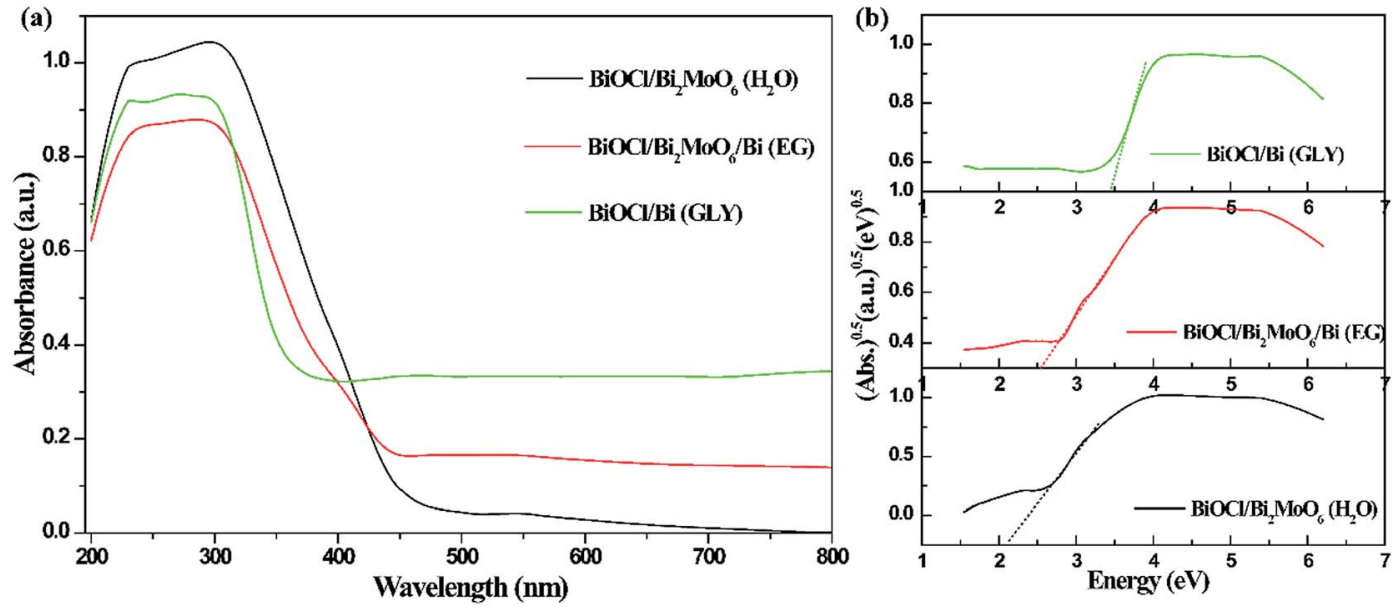

Fig. 5 UV-vis diffuse reflectance spectra (a) and determination of optical band gap (b) of the as-prepared samples. 

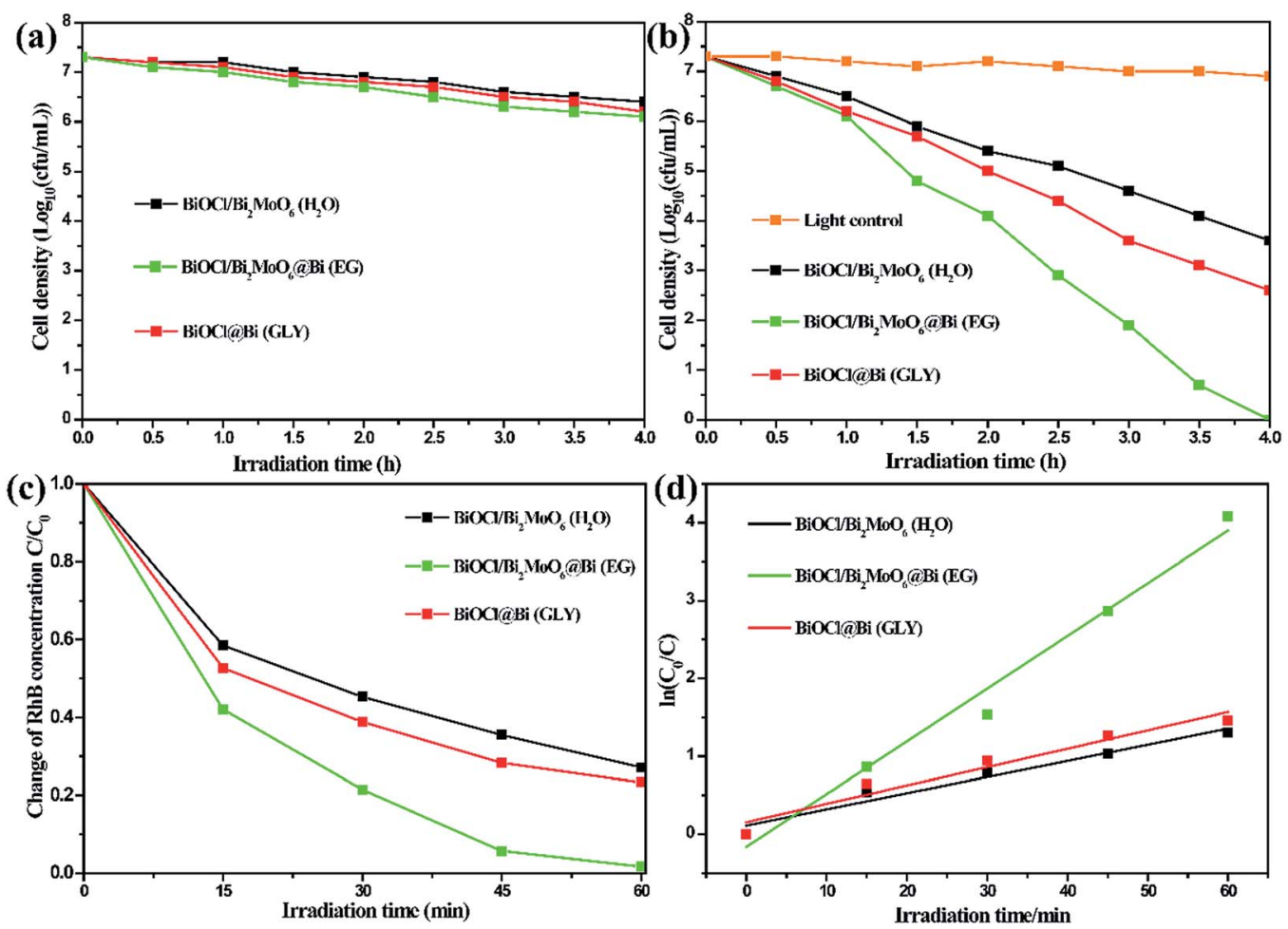

(e)

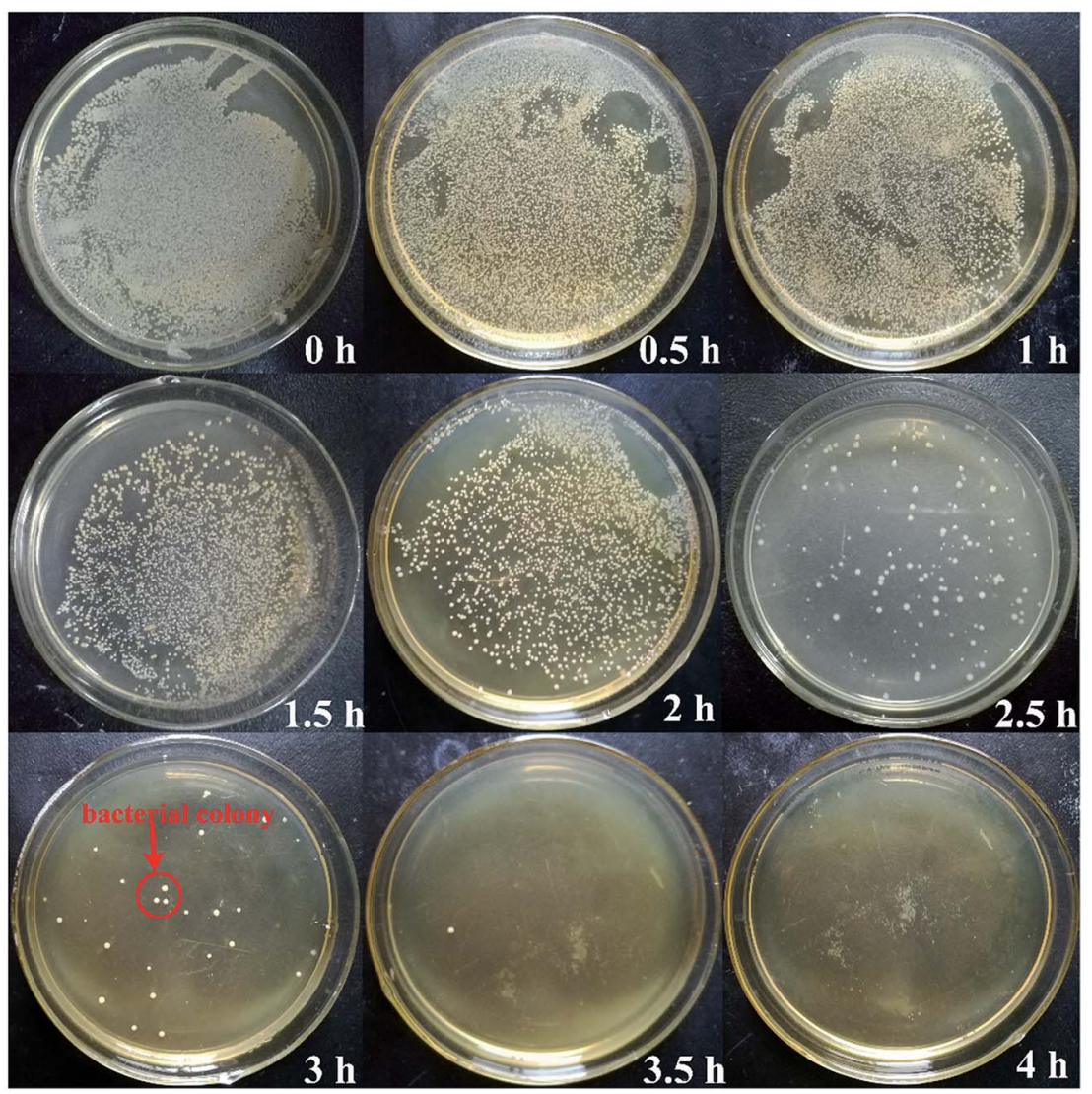

Fig. 6 (a), (b) Photocatalytic disinfection of different three samples under dark and visible-light irradiation; (c) photodegradation curves of RhB and (d) corresponding apparent rate constants of five different samples under visible-light irradiation; (e) bacterial colonies of re-cultured Staphylococcus aureus after in presence of $\mathrm{BiOCl} / \mathrm{Bi}_{2} \mathrm{MoO}_{6} / \mathrm{Bi}$ ternary composite at different times. 
photocatalytic activity in comparison with the two binary samples owing to the synergistic effect of the heterostructure and metallic Bi decoration; the water disinfection with $100 \%$ inactivation of bacteria was achieved under visible-light irradiation within $4 \mathrm{~h}$. The bacterial colonies of re-cultured Staphylococcus aureus after in presence of $\mathrm{BiOCl} / \mathrm{Bi}_{2} \mathrm{MoO}_{6} / \mathrm{Bi}$ ternary composite at different times are presented in Fig. 6e.

Similar to the photocatalytic disinfection of bacteria, the ternary $\mathrm{BiOCl} / \mathrm{Bi}_{2} \mathrm{MoO}_{6} / \mathrm{Bi}$ presents the highest $\mathrm{RhB}$ photodegradation efficiency when compared with the other two samples and RhB can be degraded completely within $60 \mathrm{~min}$. However, only $80.7 \%$ and $72.8 \%$ of RhB could be eliminated by $\mathrm{BiOCl} / \mathrm{Bi}_{2} \mathrm{MoO}_{6}\left(\mathrm{H}_{2} \mathrm{O}\right)$ and $\mathrm{BiOCl} / \mathrm{Bi}$ (GLY), respectively. Fig. 6d shows the corresponding kinetic curves for RhB photodegradation catalyzed by the three samples. Under visible-light irradiation, the kinetic constant of $\mathrm{RhB}$ degradation was $0.0677 \mathrm{~min}^{-1}$ for $\mathrm{BiOCl} / \mathrm{Bi}_{2} \mathrm{MoO}_{6} / \mathrm{Bi}$, approximately 3 times higher than those observed for $\mathrm{BiOCl} / \mathrm{Bi}_{2} \mathrm{MoO}_{6}\left(0.0207 \mathrm{~min}^{-1}\right)$ and $\mathrm{BiOCl} / \mathrm{Bi}\left(0.0236 \mathrm{~min}^{-1}\right)$.

In order to optimize the photocatalytic activity of $\mathrm{BiOCl} /$ $\mathrm{Bi}_{2} \mathrm{MoO}_{6} / \mathrm{Bi}$, different concentrations of $\mathrm{Na}_{2} \mathrm{MoO}_{4}$ were added to $\mathrm{BiOCl}$ in EG during the fabrication process. From the XRD patterns recorded for the samples (Fig. S4 $\dagger$ ), it can be observed that only $\mathrm{BiOCl}$ and $\mathrm{Bi}$ phases were formed when molar ratio of $\mathrm{BiOCl} / \mathrm{Na}_{2} \mathrm{MoO}_{4}$ was $30: 1$ and $10: 1$ (Fig. S4a and $\mathrm{b} \dagger$ ); no trace of $\mathrm{Bi}_{2} \mathrm{MoO}_{6}$ was observed. The intensity of the BiOCl diffraction peaks gradually decreased with the decrease in the molar ratio of $\mathrm{BiOCl} / \mathrm{Na}_{2} \mathrm{MoO}_{4}$, while those of $\mathrm{Bi}$ and $\mathrm{Bi}_{2} \mathrm{MoO}_{6}$, marked with the symbols $(\bullet)$ and $(\bullet)$, respectively, were strengthened (Fig. S4c-e $\dagger$ ). The photocatalytic disinfection of bacteria and $\mathrm{RhB}$ photodegradation curves obtained for the $\mathrm{BiOCl} / \mathrm{Bi}_{2} \mathrm{MoO}_{6} /$ Bi composites with different $\mathrm{BiOCl} / \mathrm{Na}_{2} \mathrm{MoO}_{4}$ molar ratios are shown in Fig. S5. $\dagger$ The photocatalytic activity of the BiOCl/ $\mathrm{Bi}_{2} \mathrm{MoO}_{6} / \mathrm{Bi}$ composites first increases and then decreases with the decrease in the initial molar ratio of $\mathrm{BiOCl} / \mathrm{Na}_{2} \mathrm{MoO}_{4}$. When the molar ratio of $\mathrm{BiOCl} / \mathrm{Na}_{2} \mathrm{MoO}_{4}$ was $6: 1$, the as-synthesized sample presented the highest photocatalytic activity.
It is important to investigate the stability and recyclability of the photocatalysts. The recyclability of the $\mathrm{BiOCl} / \mathrm{Bi}_{2} \mathrm{MoO}_{6} / \mathrm{Bi}$ ternary composite $(R=6: 1)$ was examined over four cycles. As shown in Fig. S6, $\uparrow$ the degradation efficiencies for the 4 cycles were $99.31 \%, 96.42 \%, 93.85 \%$ and $90.95 \%$ after $60 \mathrm{~min}$ of visible-light irradiation. This confirms that the $\mathrm{BiOCl} / \mathrm{Bi}_{2} \mathrm{MoO}_{6} /$ Bi ternary composite has good stability during the photocatalysis.

Furthermore, $\mathrm{Na}_{2} \mathrm{WO}_{4}$ was also introduced into the precursor dispersion of BiOCl. Similar to the composites obtained on addition of $\mathrm{Na}_{2} \mathrm{MoO}_{4}$, only binary $\mathrm{BiOCl} / \mathrm{Bi}_{2} \mathrm{WO}_{6}$ and $\mathrm{BiOCl} / \mathrm{Bi}$ were generated in $\mathrm{H}_{2} \mathrm{O}$ and GLY, respectively. The $\mathrm{BiOCl} / \mathrm{Bi}_{2} \mathrm{WO}_{6} / \mathrm{Bi}$ ternary composite was obtained when EG was used as the solvent (Fig. 7a-c). Besides, all the diffraction peaks of these catalysts can be well indexed to tetragonal $\mathrm{BiOCl}$ (JCPDS Card no. 82-0485), tetragonal $\mathrm{Bi}_{2} \mathrm{WO}_{6}$ (JCPDS Card no. 73-2020) and rhombic Bi (JCPDS Card no. 85-1329). The corresponding photocatalytic activities of the samples are presented in Fig. $7 \mathrm{~d}$. BiOCl/ $\mathrm{Bi}_{2} \mathrm{WO}_{6} / \mathrm{Bi}$ formed in $\mathrm{EG}$ was noted to exhibit a much higher photodegradation when compared with the other two samples owing to the synergistic effect of the heterostructure and metal decoration.

\subsection{Photocatalytic mechanism}

The nitrogen adsorption-desorption isotherms and BarrettJoyner-Halenda (BJH) pore-size distributions of the three samples are shown in Fig. S7. $\dagger$ All the photocatalysts formed in the three solvents possess type IV isotherms with a typical H3 hysteresis loop, implying the presence of mesopores according to the Brunauer-Dening-Dening-Teller (BDDT) classification. ${ }^{\mathbf{4 1}}$ This was further demonstrated by the pore-size distributions of the samples, which was mainly distributed in the range of 3$20 \mathrm{~nm}$ (inset of Fig. S7†). The mesoporous structure is beneficial for the adsorption and transition of $\mathrm{RhB}$ or its intermediates during the degradation process. The Brunauer-Emmett-Teller (BET) specific surface area is a potential factor that influences the photocatalytic activity. A large surface area not only
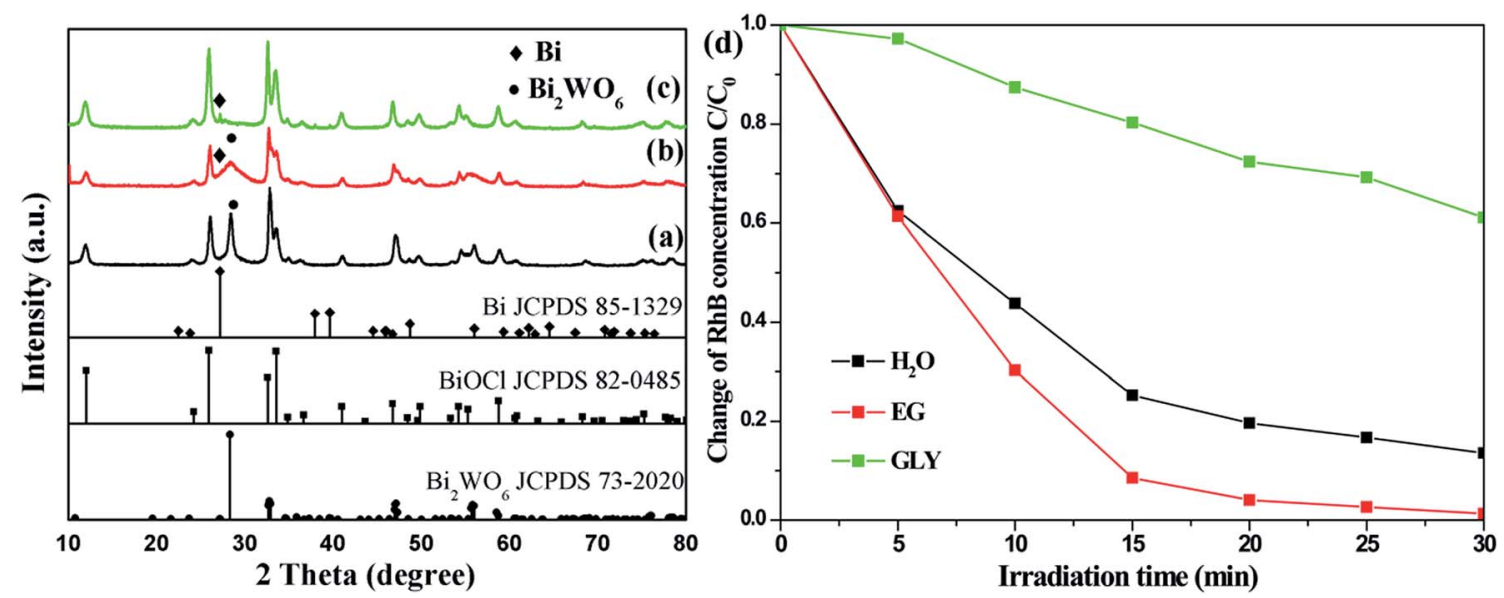

Fig. 7 XRD patterns of (a) $\mathrm{BiOCl} \mathrm{Bi}_{2} \mathrm{WO}_{6}\left(\mathrm{H}_{2} \mathrm{O}\right)$, (b) $\mathrm{BiOCl} / \mathrm{Bi}_{2} \mathrm{WO}_{6} / \mathrm{Bi}(\mathrm{EG})$, and (c) $\mathrm{BiOCl} / \mathrm{Bi}(\mathrm{GLY})$ and their corresponding photocatalytic activity (d). 
enhances the contact area between the photocatalyst and dye molecules but also provides more active sites during the reaction process. ${ }^{42,43}$ As shown in Table $\mathrm{S} 1, \dagger$ the specific surface area of $\mathrm{BiOCl} / \mathrm{Bi}_{2} \mathrm{MoO}_{6} / \mathrm{Bi}$ formed in $\mathrm{EG}$ was $126.5 \mathrm{~m}^{2} \mathrm{~g}^{-1}$, which was much higher than that of $\mathrm{BiOCl} / \mathrm{Bi}_{2} \mathrm{MoO}_{6}\left(62.8 \mathrm{~m}^{2} \mathrm{~g}^{-1}\right)$ and $\mathrm{BiOCl} / \mathrm{Bi}\left(77.0 \mathrm{~m}^{2} \mathrm{~g}^{-1}\right)$. Based on these results, it can be reasonably deduced that the specific surface area and porosity are possible reasons for the enhanced photocatalytic activity of the materials.

Photoluminescence (PL) measurements are useful for examining the migration and recombination of photogenerated electron-hole pairs in semiconductors as PL emission primarily originates from the recombination of photogenerated charge carriers. ${ }^{44}$ Fig. 8 a presents the PL spectra of the photocatalysts in the range of $300-800 \mathrm{~nm}$ under excitation at $285 \mathrm{~nm}$. It can be clearly seen that the introduction of $\mathrm{Bi}_{2} \mathrm{MoO}_{6}$ and $\mathrm{Bi}$ significantly quenches the excitonic emission when compared to that observed for the other samples. The weak PL peak intensity indicates that the heterostructure and decorated metal particles could effectively suppress the recombination of photogenerated electron-hole pairs, leading to an evident separation of the photogenerated charge carriers.

The interfacial charge transfer dynamics in the photocatalytic reaction can also be examined by photocurrent measurements. Typically, the higher photocurrent intensity suggests the higher separation efficiency of photogenerated charges. ${ }^{17,45}$ Fig. $8 \mathrm{~b}$ shows the photocurrent-time curves obtained for the three samples under several on/off visible-light irradiation cycles. $\mathrm{BiOCl} / \mathrm{Bi}_{2} \mathrm{MoO}_{6} / \mathrm{Bi}$ possesses a significantly enhanced photocurrent response, suggesting that the photogenerated electron-hole pairs could be separated more effectively than that in the other two samples. This factor could contribute to strengthening the photocatalytic activity of BiOCl/ $\mathrm{Bi}_{2} \mathrm{MoO}_{6} / \mathrm{Bi}$.

To further investigate the charge separation and migration of the as-synthesized samples, electrochemical impedance spectroscopy (EIS) was performed before and after visible-light irradiation. Fig. 8c provides the typical Nyquist plots of the three photocatalysts formed in the different solvents. These plots were best fitted to the equivalent Randle circuit of $R_{\mathrm{S}}\left(Q_{1^{-}}\right.$ $\left.R_{\mathrm{ct}}\right)$ as shown in the inset of Fig. 8c; where, $R_{\mathrm{s}}, Q_{1}$ and $R_{\mathrm{ct}}$ represent the electrolyte resistance, constant phase element and charge transfer resistance, respectively. The EIS results reveal that the diameter of the arc in the Nyquist plot of BiOCl/ $\mathrm{Bi}_{2} \mathrm{MoO}_{6} / \mathrm{Bi}$ is significantly smaller than that of the other two samples. A lower $R_{\mathrm{ct}}$ value indicates more effective separation of photogenerated electron-hole pairs and faster interfacial charge-transfer occurred in the case of $\mathrm{BiOCl} / \mathrm{Bi}_{2} \mathrm{MoO}_{6} / \mathrm{Bi}$.
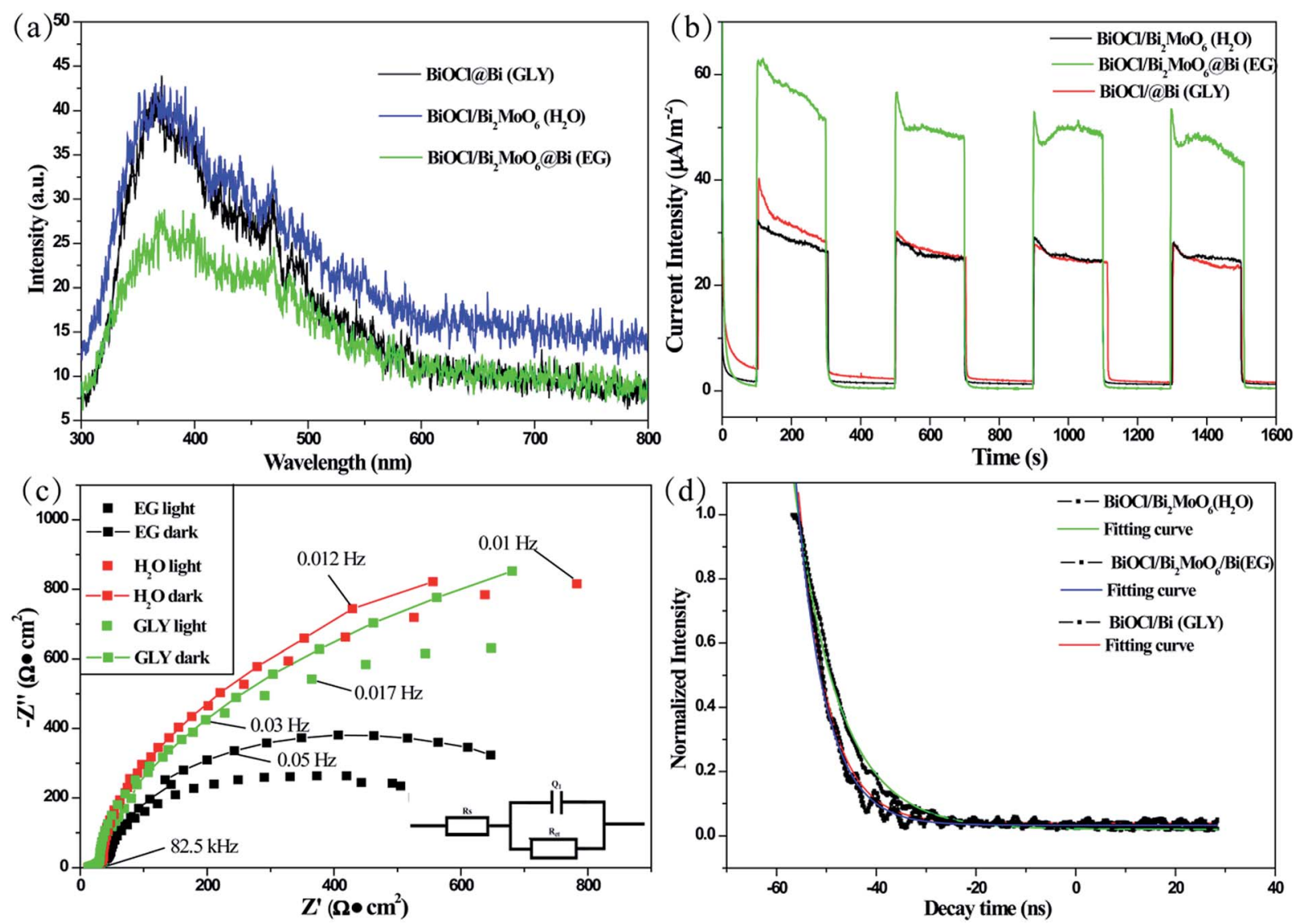

Fig. 8 (a) PL spectra of the as-prepared samples under 285 excitations. (b) Comparison of the transient photocurrent responses of the different samples under visible-light irradiation $\left(\lambda>420 \mathrm{~nm}\right.$, $\left.\left[\mathrm{Na}_{2} \mathrm{SO}_{4}\right]=0.1 \mathrm{M}\right)$. (c) EIS Nyquist plots of the photocatalysts with light on/off cycles under irradiation with visible light $\left(\lambda>420 \mathrm{~nm},\left[\mathrm{Na}_{2} \mathrm{SO}_{4}\right]=0.1 \mathrm{M}\right)$ and the corresponding schematic (inset) of the equivalent circuit obtained by fitting the EIS results. (d) The PL decay curves of the materials excited at $228 \mathrm{~nm}$ and monitored at $395 \mathrm{~nm}$. 
Therefore, $\mathrm{BiOCl} / \mathrm{Bi}_{2} \mathrm{MoO}_{6} / \mathrm{Bi}$ presents the best photocatalytic activity.

The PL decay curves obtained for the photocatalysts were examined with a $228 \mathrm{~nm}$ and $395 \mathrm{~nm}$ laser as excitation and monitored source, respectively. As shown in Fig. 8d, all the plots can be well fitted with a single exponential function, $I(t)=I_{0}+$ $A \exp (-t / \tau)$, where $I$ and $I_{0}$ are the luminescence intensity at time $t$ and $0, A$ is a constant, $\tau$ is the decay time for the exponential component. The lifetime of $\mathrm{BiOCl} / \mathrm{Bi}_{2} \mathrm{MoO}_{6} / \mathrm{Bi}(5.72 \mathrm{~ns})$ was the shortest when compared to those of $\mathrm{BiOCl} / \mathrm{Bi}_{2} \mathrm{MoO}_{6}$ (8.97 $\mathrm{ns}$ ) and $\mathrm{BiOCl} / \mathrm{Bi}(5.85 \mathrm{~ns}$ ). This was attributed to the photogenerated electron transfer from $\mathrm{Bi}_{2} \mathrm{MoO}_{6}$ to $\mathrm{BiOCl}$ and Bi. This result is consistent with the above discussions including PL measurement, photocurrent response and EIS study.

In order to determine the major active species during the photodegradation process, various scavengers including $\mathrm{p}-\mathrm{BQ}$, EDTA-2Na and IPA were added. As shown in Fig. 9a, only a weak inhibition was observed during the disinfection of bacteria upon the addition of IPA. However, the photocatalytic inactivation efficiency was largely inhibited when EDTA-2Na and BQ were introduced, suggesting that ${ }^{\circ} \mathrm{OH}$ plays a minor role in the degradation process, while $\mathrm{h}^{+}$and ${ }^{\circ} \mathrm{O}_{2}{ }^{-}$primarily govern the photocatalytic system. The results of the species trapping experiments for RhB degradation are similar to photocatalytic disinfection (Fig. 9b). In order to further confirm the
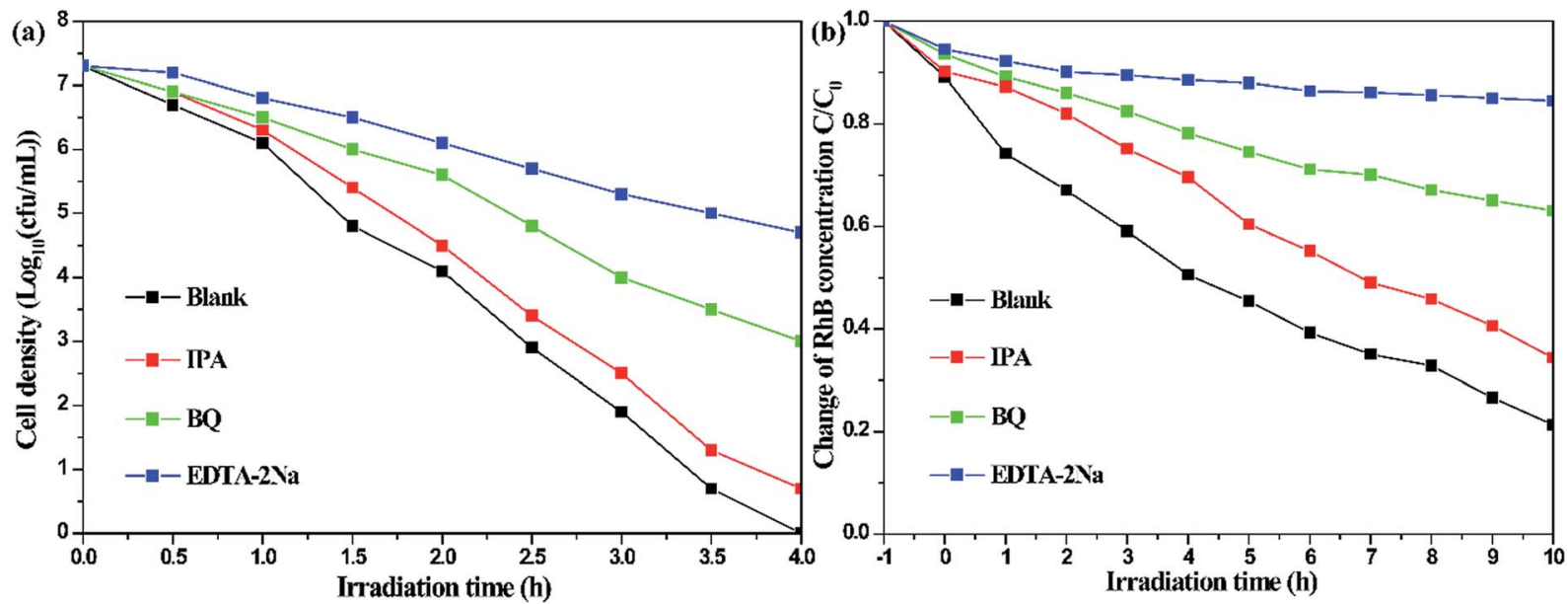

Fig. 9 Photocatalytic disinfection of bacteria (a) and $\mathrm{RhB}$ photodegradation (b) over $\mathrm{BiOCl} / \mathrm{Bi}_{2} \mathrm{MoO}_{6} / \mathrm{Bi}$ under visible-light irradiation in the presence of different scavengers.
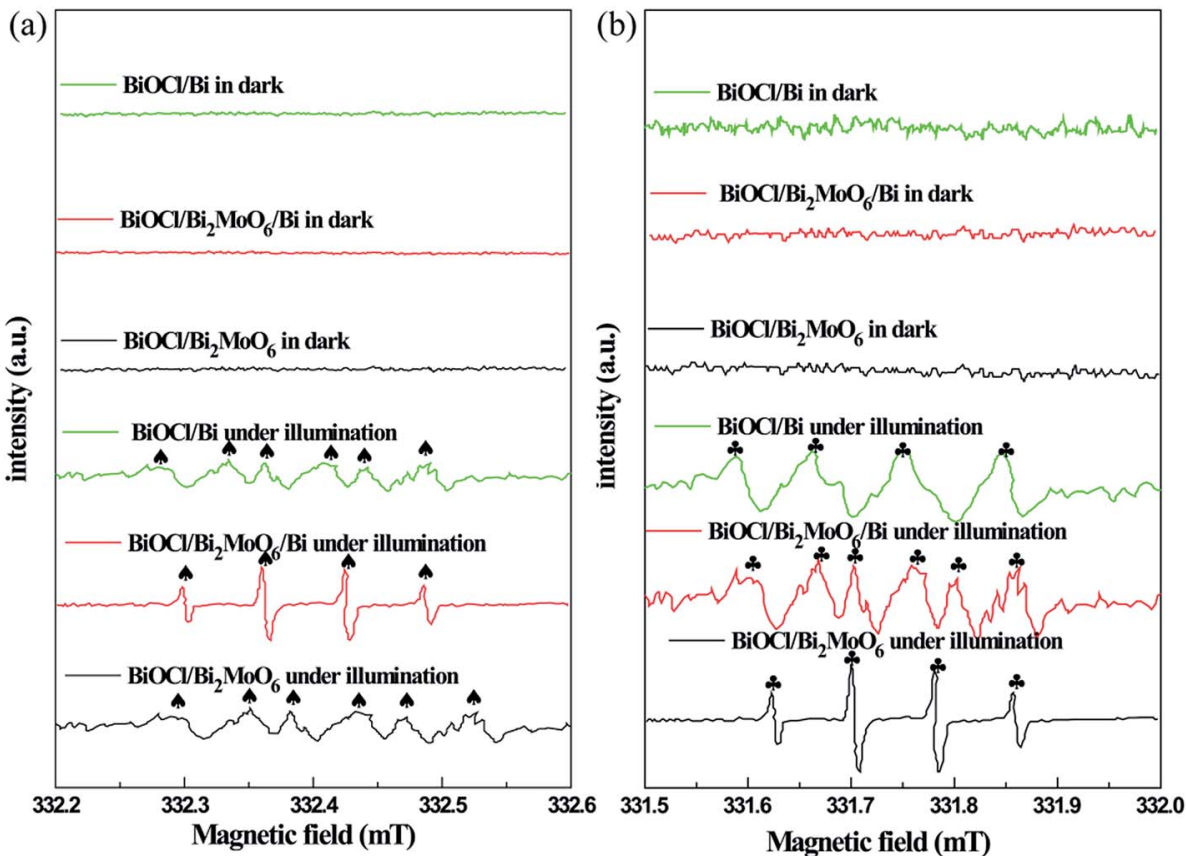

Fig. 10 DMPO spin-trapping ESR spectra measured in three samples suspensions under visible-light irradiation for $\mathrm{DMPO}-{ }^{\circ} \mathrm{OH}$ in an aqueous dispersion (a) and for DMPO- ${ }^{-} \mathrm{O}_{2}^{-}$in methanol dispersion (b). 
active species during photodegradation under visible-light irradiation, electron spin resonance (ESR) spin-trap technique using 5,5-dimethyl-1-pyrroline-N-oxide (DMPO) was carried out. In Fig. 10a, four characteristic peaks for $\mathrm{DMPO}{ }^{-} \mathrm{OH}$ can be observed in an aqueous dispersion of $\mathrm{BiOCl} / \mathrm{Bi}_{2} \mathrm{MoO}_{6} / \mathrm{Bi}$, whereas six peaks were observed with the $\mathrm{BiOCl} / \mathrm{Bi}_{2} \mathrm{MoO}_{6}$ and $\mathrm{BiOCl} / \mathrm{Bi}$ composites. Furthermore, DMPO- ${ }^{-} \mathrm{O}_{2}{ }^{-}$adducts are also detected in methanol dispersions of the three samples, where six characteristic peaks can be observed in $\mathrm{BiOCl} /$ $\mathrm{Bi}_{2} \mathrm{MoO}_{6} / \mathrm{Bi}$ (Fig. 10b). However, only four signals were observed in the other dispersions. No such signals for the two active adducts were measured in the dark. This fact suggests that visible-light irradiation is a vital factor to the formation of the active species. Both the ${ }^{\circ} \mathrm{OH}$ and ${ }^{\circ} \mathrm{O}_{2}{ }^{-}$adducts were generated in the suspensions of the three samples, with ${ }^{\circ} \mathrm{O}_{2}{ }^{-}$radicals as the dominant species.

The high photocatalytic performance of $\mathrm{BiOCl} / \mathrm{Bi}_{2} \mathrm{MoO}_{6} / \mathrm{Bi}$ could be attributed to the synergistic effect of the heterostructure construction and $\mathrm{Bi}$ decoration. The possible photocatalytic disinfection mechanism is shown schematically in Fig. 11a. Furthermore, the band edge potentials of the CB and $\mathrm{VB}$ for $\mathrm{Bi}_{2} \mathrm{MoO}_{6}$ are -0.34 and $2.20 \mathrm{~V}$ (vs. NHE), ${ }^{46}$ while those for BiOCl are 0.26 and $3.56 \mathrm{~V}$ (vs. NHE), ${ }^{47}$ respectively. Based on these results, only $\mathrm{Bi}_{2} \mathrm{MoO}_{6}$, with a narrow band gap (2.54 eV), was photoexcited under visible-light irradiation to generate electron-hole pairs. Since the $\mathrm{CB}$ of $\mathrm{Bi}_{2} \mathrm{MoO}_{6}$ is more negative than that of $\mathrm{BiOCl}$, the photogenerated electrons in the $\mathrm{CB}$ of $\mathrm{Bi}_{2} \mathrm{MoO}_{6}$ would easily inject into the $\mathrm{CB}$ edge of BiOCl. Moreover, the work function of $\mathrm{Bi}$ is $-0.31 \mathrm{~V}$ (vs. NHE), ${ }^{48}$ which is lower than that of $\mathrm{Bi}_{2} \mathrm{MoO}_{6}$ and higher than that of $\mathrm{BiOCl}$. Therefore, the photogenerated electrons could be transferred from $\mathrm{Bi}_{2} \mathrm{MoO}_{6}$ to metallic $\mathrm{Bi}$ on its surface owing to the energylevels matching. ${ }^{39,49}$ Furthermore, due to their Schottky barriers at the metal-semiconductor interface, few of the photoinduced electrons generated on the $\mathrm{CB}$ of $\mathrm{Bi}_{2} \mathrm{MoO}_{6}$ can also be transferred to $\mathrm{Bi}^{50}$ In this way, the photoinduced charge carriers could be separated efficiently. The electrons reserved in the metallic $\mathrm{Bi}$ are trapped by $\mathrm{O}_{2}$ on the surface of the photocatalyst

(a)
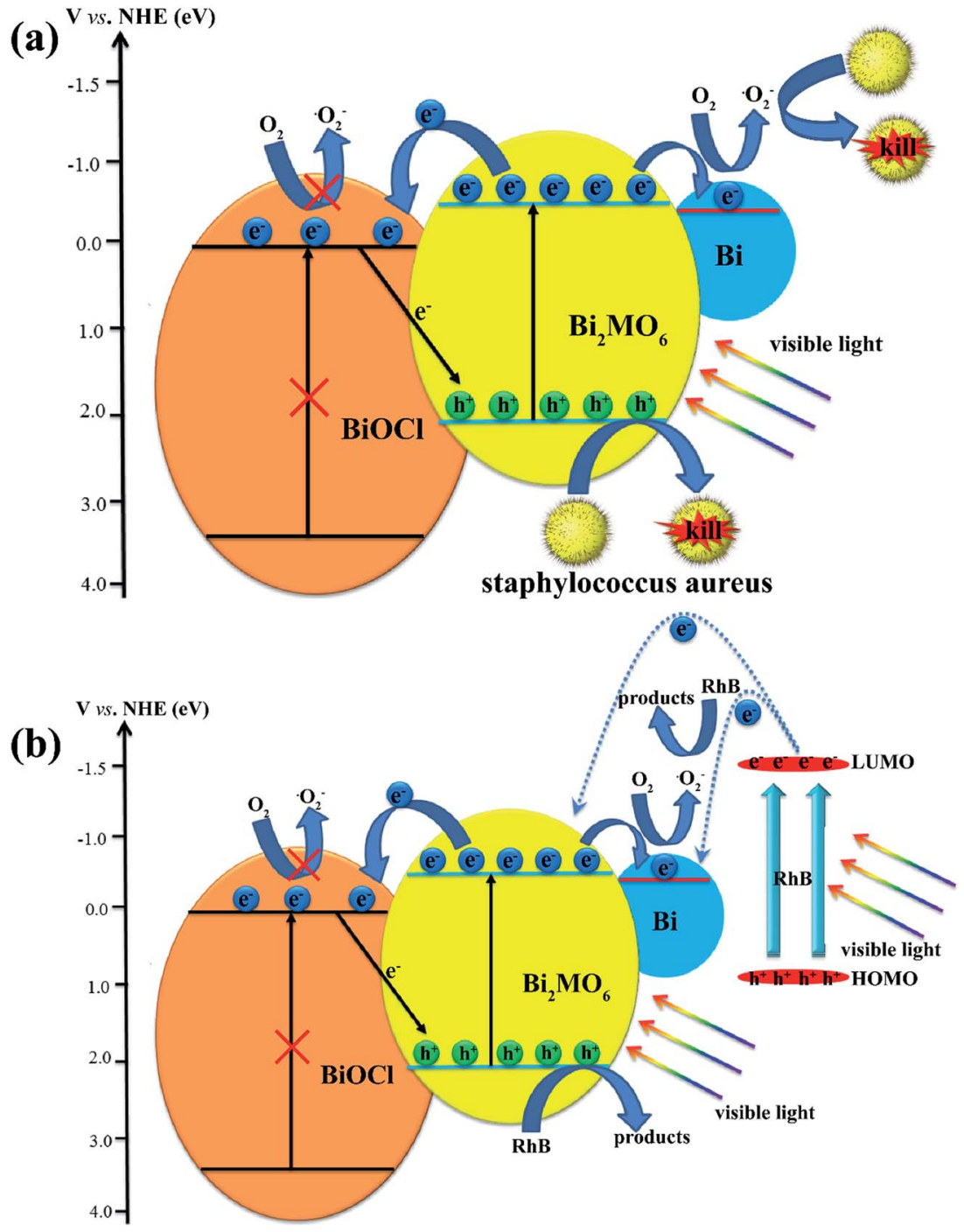

Fig. 11 Possible mechanism for the photocatalytic disinfection of bacteria (a) and $\mathrm{RhB}$ photodegradation (b) using the ternary $\mathrm{BiOCl} / \mathrm{Bi}_{2} \mathrm{MoO}_{6} / \mathrm{Bi}$ composite. 

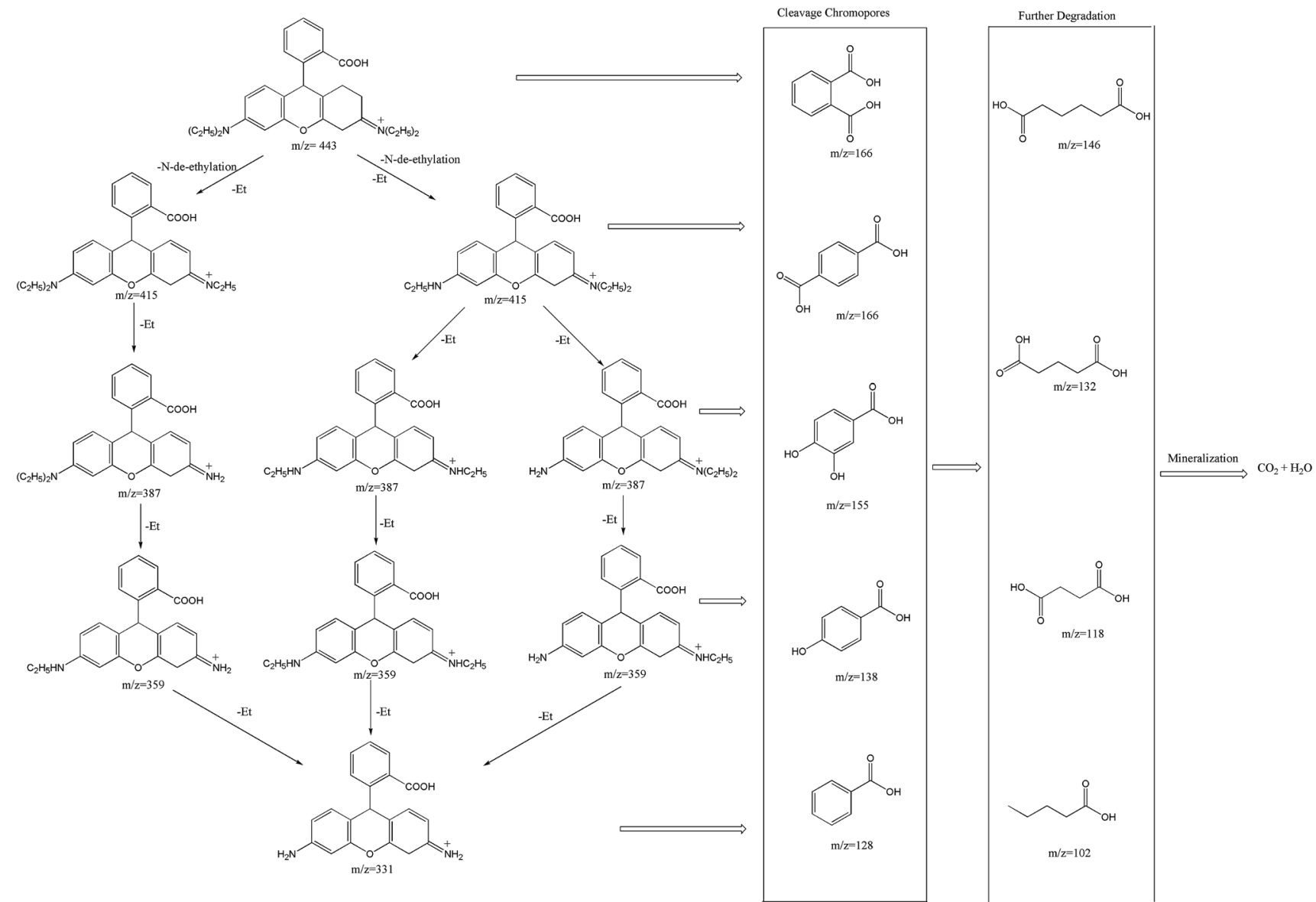

Fig. 12 Plausible degradation pathway for $\mathrm{RhB}$ dye in the $\mathrm{BiOCl} / \mathrm{Bi}_{2} \mathrm{MoO}_{6} / \mathrm{Bi}$ suspension irradiated with visible-light.

to form reactive ${ }^{\circ} \mathrm{O}_{2}{ }^{-}$, which was confirmed as one of the main active species in the photocatalytic disinfection of bacteria since the $\mathrm{CB}$ of BiOCl was $0.26 \mathrm{~V}$ (vs. NHE), while the $E^{\Phi}\left(\mathrm{O}_{2} /{ }^{\circ} \mathrm{O}_{2}{ }^{-}\right)$was $-0.046 \mathrm{~V}$ (vs. NHE). ${ }^{51}$ Therefore, no ${ }^{\circ} \mathrm{O}_{2}{ }^{-}$could be generated in BiOCl. Simultaneously, holes, as another main active adduct left behind in the $\mathrm{VB}$ of $\mathrm{Bi}_{2} \mathrm{MoO}_{6}$, would also attack the bacteria of Staphylococcus aureus. As for $\mathrm{RhB}$ photodegradation (Fig. 11b), the dye-sensitized effect would be considered in this system. The lowest unoccupied molecular orbital (LUMO) was $-1.42 \mathrm{eV},{ }^{52,53}$ which was much more negative than the $\mathrm{CB}$ of $\mathrm{Bi}_{2} \mathrm{MoO}_{6}$ and $\mathrm{Bi}$. The adsorbed $\mathrm{RhB}$ can be excited by visiblelight irradiation and the photoinduced electrons could transfer to the $\mathrm{CB}$ of $\mathrm{Bi}_{2} \mathrm{MoO}_{6}$ and $\mathrm{Bi}$, accelerating the $\mathrm{RhB}$ photodegradation.

Furthermore, the degradation intermediates of $\mathrm{RhB}$ were examined by LC-MS/MS (Fig. S8 ${ }^{\dagger}$ ). According to the results and previous studies, ${ }^{54-56}$ a plausible photodegradation pathway was reasonably proposed as depicted in Fig. 12. Two competitive processes appeared synchronously during the photocatalytic activity: $N$-de-ethylation and destruction of the chromophore structure. From the LC-MS/MS chromatogram, it can be observed that the $\mathrm{m} / \mathrm{z}$ value of 443 belongs to $\mathrm{RhB}$ and the mass peaks at $m / z 415,387,359$ and 331 are ascribed to its intermediates, such as $N, N$-diethyl- $N{ }^{\prime}$-ethylrhodamine, $N, N$-diethylrhodamine, $N$-ethyl- $N^{\prime}$-ethylrhodamine, $N$-ethylrhodamine, respectively, suggesting a series of $N$-de-ethylated intermediates could be produced step by step. Furthermore, as shown in Fig. 12, the facile chromophore cleavage of the $N$-de-ethylated intermediates simultaneously occurred throughout the photocatalytic process, which can be oxidized into phthalic acid $(\mathrm{m} / \mathrm{z}$ $=166)$, terephthalic acid $(\mathrm{m} / \mathrm{z}=166), 3,4$-dihydroxybenzoic acid ( $m / z=155)$, 4-hydroxybenzoic acid $(\mathrm{m} / \mathrm{z}=138)$, benzoic acid $(\mathrm{m} /$ $z=122)$, adipic acid $(\mathrm{m} / \mathrm{z}=146)$, glutaric acid $(\mathrm{m} / \mathrm{z}=132)$, succinic acid $(m / z=118)$ and pentanoic acid $(m / z=102)$ by ${ }^{\circ} \mathrm{O}_{2}{ }^{-}$ and $\mathrm{h}^{+}$formed under visible-light irradiation. Finally, the generated intermediates were mineralized into $\mathrm{CO}_{2}$ and $\mathrm{H}_{2} \mathrm{O}$ when the duration of visible-light irradiation was prolonged.

\section{Conclusions}

In summary, a noble-metal-free heterostructural BiOCl/ $\mathrm{Bi}_{2} \mathrm{MoO}_{6} / \mathrm{Bi}$ ternary composite was fabricated using a facile onestep hydrothermal method for the first time. The BiOCl/ $\mathrm{Bi}_{2} \mathrm{MoO}_{6} / \mathrm{Bi}$ ternary composite was formed after $\mathrm{Na}_{2} \mathrm{MoO}_{4}$ was added to $\mathrm{BiOCl}$ in EG. Only binary $\mathrm{BiOCl} / \mathrm{Bi}_{2} \mathrm{MoO}_{6}$ and $\mathrm{BiOCl} / \mathrm{Bi}$ photocatalysts were obtained in the other two solvents, $\mathrm{H}_{2} \mathrm{O}$ and GLY, respectively. Furthermore, $\mathrm{Na}_{2} \mathrm{WO}_{4}$ was also introduced into the precursor dispersion of BiOCl. Similarly, only binary $\mathrm{BiOCl} / \mathrm{Bi}_{2} \mathrm{WO}_{6}$ and $\mathrm{BiOCl} / \mathrm{Bi}$ were generated in $\mathrm{H}_{2} \mathrm{O}$ and GLY, respectively. The $\mathrm{BiOCl} / \mathrm{Bi}_{2} \mathrm{WO}_{6} / \mathrm{Bi}$ ternary composite was 
obtained when EG was used as the solvent. Under visible-light irradiation, $\mathrm{BiOCl} / \mathrm{Bi}_{2} \mathrm{MoO}_{6} / \mathrm{Bi}$ and $\mathrm{BiOCl} / \mathrm{Bi}_{2} \mathrm{WO}_{6} / \mathrm{Bi}$ were noted to exhibit the highest photocatalytic activity when compared with the other two binary samples due to the synergistic effect of the heterostructure and metal decoration, and water disinfection with $100 \%$ inactivation of bacteria was realized within $4 \mathrm{~h}$. By varying the initial ratio of BiOCl and $\mathrm{Na}_{2} \mathrm{MoO}_{4}$, the degradation performance of the $\mathrm{BiOCl} / \mathrm{Bi}_{2} \mathrm{MoO}_{6} /$ $\mathrm{Bi}$ ternary sample could be gradually tuned. The photocatalytic activity of $\mathrm{BiOCl} / \mathrm{Bi}_{2} \mathrm{MoO}_{6} / \mathrm{Bi}$ first increased and then decreased with increase in the $\mathrm{BiOCl} / \mathrm{Na}_{2} \mathrm{MoO}_{4}$ molar ratio. The effective separation and migration of charge carriers are the main reasons for the enhanced photocatalytic activity, which were confirmed by PL measurements, photocurrent measurements, EIS and PL decay measurements. The DMPO spin-trapping ESR spectra and active species trapping experiments demonstrated $\mathrm{h}^{+}$and ${ }^{\cdot} \mathrm{O}_{2}{ }^{-}$primarily govern the photocatalytic system and a possible mechanism was reasonably proposed. Finally, the $\mathrm{RhB}$ degradation intermediates were qualitatively identified using LC-MS/MS method and a detailed degradation pathway including $N$-de-ethylation, chromophore cleavage, opening-ring and mineralization has been proposed.

\section{Conflicts of interest}

There are no conflicts to declare.

\section{Acknowledgements}

This work was supported by the Doctoral Foundation of Natural Science Foundation of Shandong Province (ZR2017BEM013) and Primary Research \& Development Plan of Shandong Province (2017GNC13110).

\section{References}

1 J. Zhang, Z. Liu and Z. Liu, ACS Appl. Mater. Interfaces, 2016, 8, 9684-9691.

2 L. Guo, K. Liang, K. Marcus, Z. Li, L. Zhou, P. D. Mani, H. Chen, C. Shen, Y. Dong, L. Zhai, K. R. Coffey, N. Orlovskaya, Y.-H. Sohn and Y. Yang, ACS Appl. Mater. Interfaces, 2016, 8, 34970-34977.

3 L. A. Horsfall, D. C. Pugh, C. S. Blackman and I. P. Parkin, J. Mater. Chem. A, 2017, 5, 2172-2179.

4 E. M. Go, T. K. Lee, S. H. Min, W. C. Jeon, B.-S. Kim, M. S. Yeom and S. K. Kwak, J. Phys. Chem. C, 2016, 120, 11068-11077.

5 M. C. Scharber, Adv. Mater., 2016, 28, 1994-2001.

6 T. Kollek, D. Wurmbrand, S. T. Birkhold, E. Zimmermann, J. Kalb, L. Schmidt-Mende and S. Polarz, ACS Appl. Mater. Interfaces, 2017, 9, 1077-1085.

7 D. Chen, G. Xie, X. Cai, M. Liu, Y. Cao and S.-J. Su, Adv. Mater., 2016, 28, 239-244.

8 C. Cho, H. Kang, S.-W. Baek, T. Kim, C. Lee, B. J. Kim and J.-Y. Lee, ACS Appl. Mater. Interfaces, 2016, 8, 27911-27919.
9 A. L. Luna, E. Novoseltceva, E. Louarn, P. Beaunier, E. Kowalska, B. Ohtani, M. A. Valenzuela, H. Remita and C. Colbeau-Justin, Appl. Catal., B, 2016, 191, 18-28.

10 Y. Hong, Y. Jiang, C. Li, W. Fan, X. Yan, M. Yan and W. Shi, Appl. Catal., B, 2016, 180, 663-673.

11 X. Pu, D. Zhang, Y. Gao, X. Shao, G. Ding, S. Li and S. Zhao, J. Alloys Compd., 2013, 551, 382-388.

12 J. Deng, H. Dai, H. Jiang, L. Zhang, G. Wang, H. He and C. T. Au, Environ. Sci. Technol., 2010, 44, 2618-2623.

13 C. Yu, W. Zhou, J. C. Yu, H. Liu and L. Wei, Chin. J. Catal., 2014, 35, 1609-1618.

14 C. Yu, W. Zhou, L. Zhu, G. Li, K. Yang and R. Jin, Appl. Catal., $B, 2016,184,1-11$.

15 H. He, S. Xue, Z. Wu, C. Yu, K. Yang, G. Peng, W. Zhou and D. Li, Chin. J. Catal., 2016, 37, 1841-1850.

16 J. Di, J. Xia, S. Yin, H. Xu, L. Xu, Y. Xu, M. He and H. Li, J. Mater. Chem. A, 2014, 2, 5340-5351.

17 Y. Ma, Z. Chen, D. Qu and J. Shi, Appl. Surf. Sci., 2016, 361, 63-71.

18 D. Yue, D. Chen, Z. Wang, H. Ding, R. Zong and Y. Zhu, Phys. Chem. Chem. Phys., 2014, 16, 26314-26321.

19 L. Ye, L. Zan, L. Tian, T. Peng and J. Zhang, Chem. Commun., 2011, 47, 6951-6953.

20 S. Shenawi-Khalil, V. Uvarov, E. Menes, I. Popov and Y. Sasson, Appl. Catal., A, 2012, 413-414, 1-9.

21 L. Yu, X. Zhang, G. Li, Y. Cao, Y. Shao and D. Li, Appl. Catal., $B, 2016,187,301-309$.

22 H. Gnayem and Y. Sasson, ACS Catal., 2013, 3, 186-191.

23 W. Yang, B. Ma, W. Wang, Y. Wen, D. Zeng and B. Shan, Phys. Chem. Chem. Phys., 2013, 15, 19387-19394.

24 B. Jin, Z. Jiao and Y. Bi, J. Mater. Chem. A, 2015, 3, 1970219705.

25 J. Di, J. Xia, M. Ji, H. Li, H. Xu, H. Li and R. Chen, Nanoscale, 2015, 7, 11433-11443.

26 C. Yu, Z. Wu, R. Liu, D. D. Dionysiou, K. Yang, C. Wang and H. Liu, Appl. Catal., B, 2017, 209, 1-11.

27 X. Ding, W. Ho, J. Shang and L. Zhang, Appl. Catal., B, 2016, 182, 316-325.

28 M. Long, W. Cai and H. Kisch, Chem. Phys. Lett., 2008, 461, 102-105.

29 S. Wang, X. Yang, X. Zhang, X. Ding, Z. Yang, K. Dai and H. Chen, Appl. Surf. Sci., 2017, 391, 194-201.

30 L. Zhang, D. A. Blom and H. Wang, Chem. Mater., 2011, 23, 4587-4598.

31 Y. Sun, Y. Sun, T. Zhang, G. Chen, F. Zhang, D. Liu, W. Cai, Y. Li, X. Yang and C. Li, Nanoscale, 2016, 8, 10774-10782.

32 X. Z. Li and F. B. Li, Environ. Sci. Technol., 2001, 35, 23812387.

33 X. Liu, H. Cao and J. Yin, Nano Res., 2011, 4, 470-482.

34 F. Dong, T. Xiong, Y. Sun, Z. Zhao, Y. Zhou, X. Feng and Z. Wu, Chem. Commun., 2014, 50, 10386-10389.

35 J.-D. Li, C.-l. Yu, W. Fang, L.-H. Zhu, W.-Q. Zhou and Q.-Z. Fan, Chin. J. Catal., 2015, 36, 987-993.

36 F.-J. Zhang, S.-F. Zhu, F.-Z. Xie, J. Zhang and Z.-D. Meng, Sep. Purif. Technol., 2013, 113, 1-8.

37 K. Lai, Y. Zhu, J. Lu, Y. Dai and B. Huang, Comput. Mater. Sci., 2013, 67, 88-92. 
38 H. Gnayem and Y. Sasson, J. Phys. Chem. C, 2015, 119, 1920119209.

39 F. Dong, Q. Li, Y. Sun and W.-K. Ho, ACS Catal., 2014, 4, 4341-4350.

40 Y. Zhou, Y. Zhang, M. Lin, J. Long, Z. Zhang, H. Lin, J. C. S. Wu and X. Wang, Nat. Commun., 2015, 6, 8340.

41 K. S. W. Sing, Pure Appl. Chem., 1985, 57, 603.

42 G. Liu, L. Wang, H. G. Yang, H.-M. Cheng and G. Q. Lu, J. Mater. Chem., 2010, 20, 831-843.

43 Y. Zhang, Y. Ma, Q. Liu, H. Jiang, Q. Wang, D. Qu and J. Shi, Ceram. Int., 2017, 43, 2598-2605.

44 C. Li, G. Chen, J. Sun, J. Rao, Z. Han, Y. Hu, W. Xing and C. Zhang, Appl. Catal., B, 2016, 188, 39-47.

45 H. Huang, Y. He, Z. Lin, L. Kang and Y. Zhang, J. Phys. Chem. C, 2013, 117, 22986-22994.

46 L. Zhou, M. Yu, J. Yang, Y. Wang and C. Yu, J. Phys. Chem. C, 2010, 114, 18812-18818.

47 J. Ren, W. Wang, M. Shang, S. Sun and E. Gao, ACS Appl. Mater. Interfaces, 2011, 3, 2529-2533.
48 H. B. Michaelson, J. Appl. Phys., 1977, 48, 4729-4733.

49 A. Furube, L. Du, K. Hara, R. Katoh and M. Tachiya, J. Am. Chem. Soc., 2007, 129, 14852-14853.

50 L. Sun, R. Zhang, Y. Wang and W. Chen, ACS Appl. Mater. Interfaces, 2014, 6, 14819-14826.

51 Y. Ma, Y. Guo, H. Jiang, D. Qu, J. Liu, W. Kang, Y. Yi, W. Zhang, J. Shi and Z. Han, New J. Chem., 2015, 39, 56125620.

52 L. Pan, J.-J. Zou, X.-Y. Liu, X.-J. Liu, S. Wang, X. Zhang and L. Wang, Ind. Eng. Chem. Res., 2012, 51, 12782-12786.

53 S. Kumar, T. Surendar, A. Baruah and V. Shanker, J. Mater. Chem. A, 2013, 1, 5333-5340.

54 T. S. Natarajan, K. Natarajan, H. C. Bajaj and R. J. Tayade, J. Nanopart. Res., 2013, 15, 1669.

55 Z. He, C. Sun, S. Yang, Y. Ding, H. He and Z. Wang, J. Hazard. Mater., 2009, 162, 1477-1486.

56 S. Rajoriya, S. Bargole and V. K. Saharan, Ultrason. Sonochem., 2017, 34, 183-194. 